\title{
Florida's Citrus Canker Eradication Program (CCEP): Annual Economic Impact on Florida's Fresh and Processed Grapefruit Industry ${ }^{1}$
}

\author{
Thomas H. Spreen, Marisa L. Zansler and Ronald P. Muraro²
}

Rapid expansion and integration of international trade, increased tourism, and changes in methods of production in recent decades have increased the likelihood of the introduction of invasive species to U.S. (United States) agriculture. Invasive species can have adverse environmental and/or economic impacts when introduced into a region. Economic impacts include marketing, production, and trade implications.

One such invasive species imposing adverse economic impacts to the Florida citrus industry is a bacterial disease known as citrus canker (caused by Xanthomonas axanopodis pv. citri). Citrus canker causes lesions on the leaves, stems, and fruit of citrus trees. The disease adversely affects the proportion of fruit intended for the fresh market, serves to weaken citrus trees, and leads to a reduction in yields and higher costs of production.

The Citrus Canker Eradication Program (CCEP) was implemented in the mid-1990s in an attempt to establish guidelines for averting the spread of the disease. Currently there is no biological or chemical cure for citrus canker. All infected trees and citrus trees within a radius of 1900 feet of an infected tree must be eradicated (1900-foot rule). On-site decontamination of grove workers, field equipment, and packinghouses is also mandatory.

The current effort to eradicate citrus canker from the industry, the CCEP, has been mired in controversy associated with public opinion and legal action. A benefit-cost analysis was conducted to determine whether the CCEP is, indeed, a useful policy tool in combating the economic ramifications associated with citrus canker.

In the analysis presented in this paper, the benefits of the CCEP are predicted through an analysis of the Florida citrus industry under the scenario that citrus canker has become endemic. The estimated net change in revenue in the fresh and processed markets and the additional costs of

1. This is EDIS document FE534, a publication of the Department of Food and Resource Economics, Florida Cooperative Extension Service, Institute of Food and Agricultural Sciences, University of Florida, Gainesville, FL. Published March 2005. Please visit the EDIS website at http://edis.ifas.ufl.edu.

Note: This article is one of a series of EDIS articles on the economic impacts of citrus canker on Florida's citrus industry. The series is available at http://edis.ifas.ufl.edu/TOPIC_CCEP.

2. Thomas H. Spreen, Professor and Chair, Department of Food and Resource Economics, University of Florida, Gainesville, FL; Marisa L. Zansler, Economist, Policy Analysis and Development, USDA/APHIS, Washington, D.C.; and Ronald P. Muraro, Professor and Extension Economist, Department of Food and Resource Economics, Citrus Research and Education Center, Lake Alfred, FL, Florida Cooperative Extension Service, Institute of Food and Agricultural Sciences, University of Florida, Gainesville, FL.

The Institute of Food and Agricultural Sciences (IFAS) is an Equal Opportunity Institution authorized to provide research, educational information and other services only to individuals and institutions that function with non-discrimination with respect to race, creed, color, religion, age, disability, sex, sexual orientation, marital status, national origin, political opinions or affiliations. U.S. Department of Agriculture, Cooperative Extension Service, University of Florida, IFAS, Florida A. \& M. University Cooperative Extension Program, and Boards of County Commissioners Cooperating. Larry Arrington, Dean 
production were the measurements of the predicted benefits.

\section{Fresh and Processed Grapefruit Analysis}

A model of the Florida grapefruit market was originally developed at the University of Florida in 1991 by Pana and later modified in 1995 by Buzby and Spreen. This model is a spatial equilibrium model of the Florida grapefruit market that assimilates supply and demand in an optimization problem, and generates equilibrium prices and quantities (Buzby and Spreen, 1995).

Florida is the dominant supplier of grapefruit in the world, accounting for nearly 50 percent of world production (FAO, 2001). Israel is the second largest world supplier at 10 percent. Therefore, an analysis of Florida grapefruit prices can be conducted considering only Florida's supply. Nearly all grapefruit produced in Florida are seedless varieties that are used for both the fresh and processed markets. In recent years, fresh utilization of Florida grapefruit yields has fluctuated between 34 and 50 percent (FASS, 2000). White seedless and red seedless grapefruit varieties are treated separately in the fresh market because of consumer preference. In recent years, red seedless grapefruit has been the preferred variety in the United States, Canada, and the European Union, and white seedless grapefruit has been favored in Japan.

In this model, nine markets are considered: eight fresh fruit markets and one processed market. The eight fresh fruit markets are the red seedless and white seedless grapefruit markets in the United States, Canada, the European Union, and Japan. A single market for grapefruit juice is also considered. The supply side of the model is similar to the world orange juice model in the way red seedless and white seedless grapefruit production is generated. The main difference is that the grapefruit model includes an endogenous allocation of fruit between fresh and processed utilization.

The model incorporates different quality standards across fresh markets. For example, the quality standard in Japan is much higher than the quality standard in the United States. This is reflected through lower packout rates for fresh fruit intended for the Japanese market.

In the grapefruit model, production is predetermined in the current season. Once the crop is allocated across fresh and processed utilization and across spatial fresh markets, packinghouse and processor prices can be established. Deduction of harvesting and marketing costs confers grower prices (on-tree), which are used to predict new plantings.

\section{Empirical Specification of Grapefruit Model}

The benefit of the Citrus Canker Eradication Program (CCEP) to the fresh and processed grapefruit sector is represented by the loss of revenue between the baseline model and the yield losses under an endemic citrus canker situation. The empirical specification of the model is presented in two sub-sections: the impact of endemic citrus canker on the annual per acre returns for Florida fresh and processed grapefruit, and market impacts on the world market for Florida red and white grapefruit. Specification of the baseline model and the model adjustments for citrus canker are outlined simultaneously in each section.

\section{Empirical Results of Model}

The empirical results are also presented in the sub-sections of the fresh and processed grapefruit analysis: the impact of endemic citrus canker on the annual per acre returns for Florida fresh and processed grapefruit, and market impacts on the world market for Florida red and white grapefruit.

\section{Annual Returns for the Fresh and Processed Grapefruiti Market in Florida}

Results of the estimated economic impact of endemic citrus canker on the annual per acre returns for Florida fresh and processed grapefruit are reported in Table 1. If citrus canker were to become endemic to Florida, total production of red seedless and white seedless grapefruit could decrease ten percent, packout rates could decline by one-third, and market access to the EU (European Union) market could be lost. As a result, fresh utilization of red seedless grapefruit would decrease by approximately 5.5 
million boxes, from 13.9 to 8.4 million boxes, and fresh utilization of white seedless grapefruit would decrease by 1.6 million boxes, from 4.3 to 2.7 million boxes. For red seedless grapefruit, the significant increase in estimated on-tree price per box from $\$ 5.52$ to $\$ 9.92$ would more than offset the reduction in fresh utilization if fresh on-tree revenues increase from $\$ 77$ million to $\$ 83.8$ million. However, fresh on-tree revenues for white seedless grapefruit are estimated to decrease from $\$ 41.8$ million to $\$ 40.7$ million despite the estimated on-tree price increase for fresh utilization from $\$ 9.78$ per box to $\$ 15.35$ per box.

While processed utilization of red seedless grapefruit is estimated to increase by approximately 25,000 boxes, from 17.954 to 17.979 million boxes, processed utilization of white seedless grapefruit is estimated to decrease by 943,000 boxes, from approximately 16.6 to 15.7 million boxes. For processed red seedless grapefruit, the on-tree price per box is estimated to decrease from $\$ 1.69$ to $\$ 1.20$, leading to a 29 percent loss in processed on-tree revenues, from $\$ 30.3$ million to $\$ 21.6$ million. Processed on-tree revenues are also estimated to decline 26 percent for white seedless grapefruit, from approximately $\$ 39.1$ million to $\$ 28.9$ million, largely in part due to the elimination charge associated with increased eliminations.

Average fresh on-tree prices are estimated to increase in an endemic citrus canker industry as a result of the lower packout rates, as reflected by the decrease in fresh utilization. It is estimated that there would be an overall estimated gain of $\$ 5.8$ million in fresh on-tree revenue associated with the endemic scenario for grapefruit. The overall processed on-tree revenue loss is estimated at $\$ 19$ million, with red seedless grapefruit losses estimated at $\$ 8.8$ million and white seedless grapefruit losses estimated at $\$ 10.2$ million. The total estimated loss of on-tree revenue as a result of endemic citrus canker is estimated to be $\$ 13.2$ million.

\section{Economic Impacts of Endemic Citrus Canker in Florida on World Red and White Grapefruit F.O.B. Revenue}

The impact of citrus canker on world F.O.B. (freight on board) revenue for red seedless and white seedless grapefruit is reported in Tables 2 and 3, respectively. According to the results of the model, the average F.O.B. (freight on board) price for both red and white grapefruit in the United States, Canada, and Japan increases significantly if citrus canker becomes endemic to the Florida citrus industry. The baseline average F.O.B. price per carton of red seedless grapefruit is $\$ 7.60, \$ 7.80, \$ 8.00$, and $\$ 10.80$ in the United States, Canada, the European Union, and Japan, respectively. The adjusted endemic citrus canker F.O.B. price for red grapefruit increases to $\$ 9.93, \$ 10.19$, and $\$ 14.16$ per carton in the United States, Canada, and Japan, respectively. The baseline average F.O.B. price per carton of white seedless grapefruit is $\$ 8.03, \$ 8.00, \$ 8.20$, and $\$ 11.00$ in the United States, Canada, and Japan, respectively. The adjusted F.O.B. price for white grapefruit increases to $\$ 10.34, \$ 10.30$, and \$14.14 in the United States, Canada, and Japan, respectively.

In a citrus canker endemic industry, Florida's marketing of fresh grapefruit would decrease in the United States, Canada, and Japan, and marketing to the European Union would be blocked entirely. Based on this information, in the United States, marketings of fresh red seedless grapefruit would decrease by 2 million cartons, from 14.2 to 12.2 million cartons, and marketings of fresh white seedless grapefruit would decrease by 192,000 cartons, from 1.5 to 1.3 million cartons. In Canada, marketings of fresh red seedless grapefruit would decrease by 287,000 cartons, from 2.1 to 1.8 million cartons, and marketings of fresh white seedless grapefruit would decresae by 22,000 cartons, from 168,000 to 146,000 cartons. In Japan, marketings of fresh red seedless grapefruit would decrease by over 2.2 million cartons, from 5 million to 2.8 million cartons, and marketings of fresh white seedless grapefruit would decrease by 2.9 million cartons, from 6.9 to 4 million cartons. Florida is estimated to lose its entire EU marketing share of roughly 6.6 million cartons of fresh red seedless grapefruit and 248,000 cartons of fresh white seedless grapefruit. 
Adjusted F.O.B. revenue in the United States is estimated to increase to $\$ 121$ million for fresh red seedless grapefruit and to $\$ 13.4$ million for white grapefruit. Adjusted F.O.B. revenue in Canada would increase to $\$ 18.3$ million for red grapefruit and to $\$ 1.5$ million for white grapefruit. Adjusted F.O.B. revenue in Japan, however, would decrease to $\$ 39.4$ million for red grapefruit and to $\$ 57$ million for white white grapefruit. Adjusted F.O.B. revenue in Canada increases to $\$ 18.3$ million for red grapefruit and to $\$ 1.5$ million for white grapefruit. Under the assumption that market access to the European Union is denied with endemic canker, the F.O.B. revenue from that market is eliminated.

Total F.O.B. revenue for fresh red seedless grapefruit would decrease roughly 23 percent, from $\$ 231.1$ million to $\$ 178.7$ million. Total F.O.B. revenue for fresh white seedless grapefruit would decrease roughly 21 percent, from $\$ 91.1$ million to $\$ 71.9$ million. Total F.O.B. revenue would decrease from $\$ 322.2$ million to $\$ 250.7$ million if citrus canker becomes endemic to Florida. Total net change in F.O.B. revenue is estimated to decline by $\$ 52.3$ million on fresh red seedless grapefruit and $\$ 19.2$ on fresh white seedless grapefruit as a result of endemic citrus canker.

\section{Additional Costs of Production}

In addition to the market analysis, partial budgeting is used to document the impact of citrus canker on production costs. Muraro, Roka, and Rouse (2000) and Muraro, Hebb, and Stover (2000) annually publish budgeting and costs of production for oranges and grapefruit produced in three regions of Florida. These studies are based on a survey of custom operators, input suppliers, and growers located in central Florida, southwest Florida, and the Indian River area of Florida. In a study published by Muraro, Roka, and Spreen (2001), grower costs were estimated based on citrus canker becoming endemic to Florida. The study reviewed citrus canker control programs implemented in Argentina for estimating cultural costs. The analysis identified six criteria for evaluating the changes in the cost structure to manage the disease as follows:
1. Capital investment cost of additional equipment for spraying.

2. Additional costs of copper sprays.

3. Costs of establishing windbreaks for fresh market varieties, including reduced production due to trees removed for windbreaks.

4. Value of fruit loss due to citrus canker infestation (reduced yields).

5. Certification fees.

6. Decontamination fees.

Muraro, Roka, and Spreen (2001b) estimate that two additional sprays would be required for fresh fruit at a cost of $\$ 59.08$ per acre. Producers of fresh fruit varieties already include copper spraying as part of their production practices; these estimated values are for additional sprays, which would be applied pre-bloom and at petal fall (Muraro, Roka, and Spreen, 2001b). For processed fruit, one additional spray would be needed at a cost of $\$ 32.36$ per acre. For the more susceptible varieties, an additional copper spray would be required at petal fall. Growers would apply additional sprays of copper to try to mitigate the adverse effect citrus canker has on both fruit appearance and yield.

A major problem facing Florida in the presence of citrus canker is its flat terrain. Since the primary vector for transmission of citrus canker is wind and rain, it would be difficult for the Florida citrus industry to keep citrus canker isolated to a confined area. Establishing windbreaks to limit the spread of canker from one grove to another will be a necessity for Florida citrus grown for the fresh fruit market and for the more susceptible early processed orange varieties. Muraro, Roka, and Spreen (2001b) estimate the annual cost of establishing and maintaining a windbreak at $\$ 44.89$ per acre.

\section{Economic Impact of Citrus Canker on Packinghouse Costs of Seedless Grapefruit}

F.O.B. costs of producing red seedless and white seedless grapefruit for the fresh market are estimated for a citrus canker endemic industry. The impact of 
citrus canker on the estimated F.O.B. packinghouse costs for red grapefruit is reported in Table 4 . The estimated production cost (which includes growing, harvesting, hauling, and packing) of grapefruit is shown based on the figures provided by Muraro, Roka, and Rouse (2000). In those production budgets, a typical southwest Florida red grapefruit grove, under the assumption of 555 boxes per acre yield and a 60 percent fresh market (packout) yield, are analyzed.

The total cartons of fresh fruit that can be marketed from one acre with a 60 percent packout are 666 (two cartons per box). Assuming that canker reduces fruit yield by ten percent, per acre yield declines from 555 boxes to 500 boxes per acre. Furthermore, assuming the packout rate declines by one-third with citrus canker, per acre fresh market utilization with endemic citrus canker is reduced from 667 cartons to 400 cartons per acre. Using the Florida market grapefruit model with citrus canker, the delivered-in price of eliminations increases from $\$ 0.60$ per pound solid to $\$ 0.65$ per pound solid because less fruit is being processed. Growing costs per acre increase through costs associated with the placement of windbreaks and additional copper applications, from $\$ 867.06$ to $\$ 971.03$. When adjusted to per carton, growing costs increase by 87 percent, from $\$ 1.30$ to $\$ 2.43$ per carton. Other costs (which include interest on operating costs, management costs, taxes, and interest on capital investment) increase from $\$ 0.83$ to $\$ 1.38$ per carton. In a canker endemic industry, harvesting costs (which include pick-and-haul) increase from $\$ 1.94$ to $\$ 2.91$ per carton as a consequence of lower packout rates.

Overall, total delivered-in costs are estimated to increase by 65 percent, from $\$ 4.07$ per carton to $\$ 6.72$ per carton. Packing and selling costs increase from $\$ 3.79$ per carton to $\$ 3.89$ per carton with the addition of certification and fees decontamination costs. Certification fees and decontamination costs were obtained from a study on estimating grower costs associated with endemic citrus canker in Florida (Muraro, Roka, and Spreen, 2001b). Certification fees include field investigation fees of $\$ 26.46$ per acre and packinghouse certification of $\$ 31.50$ per acre. Field investigation includes labor, transportation, and administrative costs. The total certification fee for red seedless grapefruit is $\$ 57.96$ per acre, or $\$ 0.07245$ per carton. In addition, decontamination of harvesting and transportation equipment, as well as trailers and workers, increases F.O.B. costs by $\$ 27.50$ per acre, or $\$ 0.034375$ per carton. Certification fees and decontamination costs increased F.O.B. costs by 10.68 cents per carton. The delivered-in net value of fresh eliminations is the average yield of pound solids per box times price per pound solids minus the packinghouse elimination charge of $\$ 1.00$ per box. After factoring in the credit associated with net costs of eliminations, total F.O.B. costs at the packinghouse level for red seedless grapefruit increase by roughly 25 percent with endemic citrus canker, from $\$ 7.248$ to $\$ 9.069$ per carton.

The impact of citrus canker on the estimated F.O.B. packinghouse costs for white grapefruit is reported in Table 5. The estimated production cost (which includes growing, harvesting, hauling, and packing) of white grapefruit is shown based on the figures provided by Muraro, Hebb, and Stover (2000). In those production budgets, Indian River white grapefruit groves, under the assumption of 469 boxes per acre yield and a 60 percent fresh market (packout) yield, are analyzed. Total cartons of fresh white seedless grapefruit that can be marketed from one acre with a 60 percent packout is 562.8 (two cartons per box). Assuming that citrus canker reduces fruit yield by ten percent, per acre yield declines from 469 boxes to 422.1 boxes per acre. Furthermore, assuming the packout rate declines by one-third with citrus canker, fresh market utilization with endemic citrus canker is reduced from 562.8 cartons to 337.7 cartons per acre. Using the Florida market grapefruit model with citrus canker, the delivered-in price of eliminations increases from $\$ 0.60$ per pound solids to $\$ 0.65$ per pound solids because less fruit will be processed. Growing costs per acre increase through costs associated with the placement of windbreaks and additional copper applications, from $\$ 951.47$ to $\$ 1055.44$. When adjusted to per carton, growing costs increase by approximately 85 percent, from $\$ 1.691$ per carton to $\$ 3.126$ per carton. Other costs (which include interest on operating costs, management costs, taxes, and interest on capital investment) increase 67 percent, from $\$ 1.128$ to $\$ 1.880$ per carton. Harvesting costs 
(which include pick-and-haul) increase from \$1.938 per carton to $\$ 2.906$ per carton.

Overall, total delivered-in costs are estimated to increase by approximately 66 percent, from $\$ 4.756$ per carton to $\$ 7.912$ per carton. Packing and selling costs increase from $\$ 3.785$ per carton to $\$ 3.886$ per carton with the addition of certification and fees decontamination costs. Certification fees and decontamination costs were obtained from a study on estimating grower costs associated with endemic citrus canker in Florida (Muraro, Roka, and Spreen, 2001b). The total certification fee for white seedless grapefruit is $\$ 57.96$ per acre, or $\$ 0.0687$ per carton. In addition, decontamination of harvesting and transportation equipment, as well as trailers and workers, increases F.O.B. costs by $\$ 27.50$ per acre, or $\$ 0.0326$ per carton. Certification fees and decontamination costs increased F.O.B. costs by 10.13 cents per carton.

The net value of fresh eliminations is the average yield of pound solids per box times price per pound solids minus the packinghouse elimination charge of $\$ 1.00$ per box. After factoring in the credit associated with net costs of eliminations, total F.O.B. costs at the packinghouse level for white seedless grapefruit increase by roughly 30 percent with endemic canker, from $\$ 7.934$ to $\$ 10.257$ per carton.

\section{Economic Impact of Citrus Canker on Field-Run Costs of Seedless Grapefruit}

Field-run costs of producing red seedless and white seedless grapefruit for the processed market are estimated for a citrus canker endemic industry. The impact of citrus canker on the estimated processed costs for field-run red grapefruit is reported in Table 6 . The estimated total delivered-in cost for red seedless grapefruit grown for the processed grapefruit market (which includes growing, harvesting, hauling, and packing) is based on the figures provided by Muraro, Roka, and Rouse (2000). In the production budget, a typical southwest Florida processed red grapefruit grove, assuming 555 boxes per acre yield, is analyzed. Assuming that citrus canker reduces fruit yield ten percent, per acre yields would decline from 555 boxes to 500 boxes per acre. Growing costs would increase from $\$ 682.92$ to 715.28 per acre due to the extra copper spray cost of $\$ 32.36$. When adjusted to boxes per acre, grower costs would increase 16 percent, from $\$ 1.23$ to $\$ 1.43$ per box. Other costs (which include interest on operating costs, management costs, taxes, and interest on capital investment) would increase 11 percent, from $\$ 0.899$ to $\$ 0.988$ per box. In a citrus canker endemic industry, harvesting and DOC assessment costs (which include pick-and-haul and DOC taxes) would increase from $\$ 2.00$ per box to $\$ 2.22$ per box. Total delivered-in costs for field run red grapefruit in an endemic citrus canker industry would increase roughly 13 percent, from $\$ 4.13$ per box to $\$ 4.65$ per box.

The impact of citrus canker on the estimated processed costs for field-run white grapefruit is reported in Table 7. The estimated total delivered-in cost for white seedless grapefruit grown for the processed grapefruit market (which includes growing, harvesting, hauling, and packing) is based on the figures provided by Muraro, Hebb, and Stover (2000). In the production budget, Indian River processed white grapefruit groves, assuming 469 boxes per acre yield, are analyzed. Under the assumption that citrus canker reduces fruit yield ten percent, per acre yields decline from 469 boxes to 422 boxes per acre. Growing costs would increase from $\$ 769.14$ to 801.50 per acre due to costs associated with the extra copper spray cost of $\$ 32.36$. When adjusted to boxes per acre, grower costs would increase 16 percent, from $\$ 1.64$ to $\$ 1.90$ per box. Other costs (which include interest on operating costs, management costs, taxes, decontamination costs for citrus canker, and interest on capital investment) would increase 11 percent, from $\$ 1.30$ to $\$ 1.44$ per box. In a citrus canker endemic industry, harvesting and DOC assessment costs (which include pick-and-haul and DOC taxes) would increase from $\$ 2.05$ per box to $\$ 2.28$ per box. Total delivered-in costs for field run white grapefruit in an endemic citrus canker industry would increase roughly 13 percent, from $\$ 4.99$ per box to $\$ 5.62$ per box.

\section{Summary of Benefits}

Table 8 summarizes the estimated net change in revenue of fresh and processed red and white seedless 
grapefruit markets when citrus canker is introduced. Under the conditions associated with an industry with endemic citrus canker, the combined fresh and processed grapefruit market is estimated to incur an overall revenue net loss of $\$ 13.2$ million. A $\$ 6.8$ million net gain in revenue is estimated for the fresh red seedless grapefruit market, and a $\$ 1.1$ million net loss in revenue is estimated for the fresh white seedless grapefruit market. The processed red and white seedless grapefruit markets are expected to experience revenue net losses of $\$ 8.8$ million and $\$ 10.2$ million, respectively. Overall, the red seedless grapefruit market (fresh and processed) would experience a $\$ 1.9$ million net loss in revenues, and the white seedless grapefruit market (fresh and processed) would experience an $\$ 11.3$ million net loss in revenues. Table 9 summarizes the estimated net change in world F.O.B. revenue for the red seedless and white seedless grapefruit markets if citrus canker occurs, showing an overall net F.O.B. revenue loss of $\$ 71.5$ million. The largest impact would be to the red seedless grapefruit market, with an estimated net loss of $\$ 52.3$ million. The impact is mostly due to the loss of the EU fresh market and a substantial increase in the Japanese F.O.B. price. This loss greatly offsets the gain in F.O.B. revenue estimated for the U.S. and Canadian markets. Under these conditions, the white seedless grapefruit market would experience an overall net loss of $\$ 19.2$ million. Again, the combined impact of the loss of EU market access and an increase in the Japanese F.O.B. price would offset the gain in F.O.B. revenue estimated for the U.S. and Canadian markets.

Table 10 summarizes the estimated net change in the production cost of red and white seedless grapefruit intended directly for the processed market (field-run) of red seedless and white seedless grapefruit being sent to packinghouses in an endemic citrus canker industry. Production costs of field-run grapefruit varieties are expected to decreased by $\$ 1.4$ million if citrus canker becomes endemic in Florida.

Packinghouse production costs of the two grapefruit varieties intended for the packinghouse would increase dramatically by $\$ 46$ million for red seedless grapefruit and $\$ 28$ million for white seedless grapefruit. The overall production cost of Florida grapefruit is estimated to increase by approximately
$\$ 72.7$ million. A summary of the total annual net effect and economic impact of endemic citrus canker is shown in Table 11. The total annual net reduction in on-tree and F.O.B. revenues and the net increase in production costs for Florida fresh and processed grapefruit is estimated to be $\$ 157.4$ million.

The effects of the 2004 hurricane season add a new unknown in the CCEP economic analysis since the citrus canker bacteria disease is spread by rain-driven wind. Results for the economic analysis were developed in June of 2004 before Hurricanes Charley, Francis, and Jeanne passed through Florida. Continuation of the CCEP beyond 2008 would require a new study to estimate the economic impact of the additional costs of the CCEP along with the losses incurred by Florida's citrus industry.

\section{References}

Animal and Plant Health Inspection Service (APHIS). 2003. Citrus Canker. Washington DC: United States Department of Agriculture. Available online at

http://www.aphis.usda.gov/ppq/ep/citruscanker.

Brown, M.A., T.H. Spreen, and R.P. Muraro. 1999. Fresh versus Processed Utilization of Florida Grapefruit. Journal of Food Distribution Research 30(3):22-32.

Buzby, J.C., and T.H. Spreen. 1995. The Impact of the U.S. Grapefruit Industry on Banning the Pesticide Sodium Ortho-Phenylphenate. Journal of Food Distribution Research 26(2):39-46.

Food and Agriculture Organization of the United Nations (FAO). 2001. Projections of World Production and Consumption of Citrus to 2010. China/FAO Citrus Symposium, Beijing, China (May).

Florida Agricultural Statistics Service (FASS). 2000. Citrus Summary 1999-2000. FASS, Orlando, FL.

Gottwald, T.R., J.H. Graham, and T.S. Schubert. 2002. Citrus Canker: The Pathogen and Its Impact. Plant Health Progress doi: 10.1094/PHP-2002-0812-01-RV. 
Graham, J.H., and T.R. Gottwald. 1991.

Research Perspectives on Eradication of Citrus

Bacterial Diseases in Florida. Plant Diseases

75:1193-1200.

Muraro, R.P., J.W. Hebb, and E.W. Stover. 2000. Budgeting Costs and Returns for Indian River

Citrus Production, 1999-2000. Economic Information Report EI-00-08. Department of Food and Resource Economics, University of Florida, Gainesville, FL (December).

Muraro, R.P., F.M. Roka, and R.E. Rouse. 2000. Budgeting Costs and Returns for Southwest Florida Citrus Production, 1999-2000. Economic Information Report EI-00-07. Department of Food and Resource Economics, University of Florida, Gainesville, FL (December).

Muraro, R. P., F. M. Roka, and T. H. Spreen. 2001a. An Overview of Argentina's Citrus Canker Control Program. Electronic Data Information Source (EDIS) FE285. Department of Food and Resource Economics, UF/IFAS, University of Florida, Gainesville, FL (June).

Muraro, R. P., F. M. Roka, and T. H. Spreen. 2001b. Grower Costs of Having Citrus Canker in Florida. Electronic Data Information Source (EDIS) FE286. Department of Food and Resource Economics, UF/IFAS, University of Florida, Gainesville, FL (June).

Pana, R. 1991. A Model of the World Market for Fresh and Processed Grapefruit. Unpublished M.S. thesis. Department of Food and Resource Economics, University of Florida, Gainesville, FL.

Zansler, M.L. 2004. The Economic Impacts to an Industry Associated with an Invasive Species: The Case of Citrus Canker in Florida. Ph.D. dissertation. Department of Food and Resource Economics, University of Florida, Gainesville, FL (August). 
Florida's Citrus Canker Eradication Program (CCEP): Annual Economic Impact on Florida's....

Table 1. Estimated economic impact of endemic citrus canker on annual returns of fresh and processed Florida grapefruit, 1999-2000 season.

\begin{tabular}{|c|c|c|c|c|c|c|c|}
\hline \multirow[t]{2}{*}{ Variety } & \multicolumn{3}{|c|}{ Fresh Fruit } & \multicolumn{3}{|c|}{ Processed Fruit } & \multirow{2}{*}{$\begin{array}{l}\text { On-Tree } \\
\text { Revenue* }^{*}\end{array}$} \\
\hline & $\begin{array}{c}\text { Fresh } \\
\text { Utilization }\end{array}$ & $\begin{array}{c}\text { Fresh } \\
\text { On-Tree } \\
\text { Price }\end{array}$ & $\begin{array}{c}\text { Fresh } \\
\text { On-Tree } \\
\text { Revenue }\end{array}$ & $\begin{array}{c}\text { Processed } \\
\text { Utilization }\end{array}$ & $\begin{array}{l}\text { Processed } \\
\text { On-Tree } \\
\text { Price }\end{array}$ & $\begin{array}{c}\text { Processed } \\
\text { On-Tree } \\
\text { Revenue }\end{array}$ & \\
\hline & $\begin{array}{l}1,000 \\
\text { boxes }\end{array}$ & $\$ / b o x$ & $\begin{array}{l}1,000 \\
\text { dollars }\end{array}$ & $\begin{array}{l}1,000 \\
\text { boxes }\end{array}$ & $\$ / b o x$ & $\begin{array}{l}1,000 \\
\text { dollars }\end{array}$ & $\begin{array}{l}1,000 \\
\text { dollars }\end{array}$ \\
\hline \multicolumn{8}{|l|}{ Without Citrus Canker } \\
\hline Red Grapefruit & 13,946 & 5.52 & 76,982 & 17,954 & 1.69 & 30,342 & 107,324 \\
\hline White Grapefruit & 4,271 & 9.78 & 41,770 & 16,629 & 2.35 & 39,078 & 80,848 \\
\hline \multicolumn{8}{|l|}{ With Citrus Canker } \\
\hline Red Grapefruit & 8,449 & 9.92 & 83,814 & 17,979 & 1.20 & 21,575 & 105,389 \\
\hline White Grapefruit & 2,651 & 15.35 & 40,693 & 15,686 & 1.84 & 28,862 & 69,555 \\
\hline
\end{tabular}

Table 2. Estimated economic impact of endemic citrus canker on world F.O.B. revenue for red seedless grapefruit, 1999-2000 season.

\begin{tabular}{|c|c|c|c|c|c|c|c|}
\hline & \multicolumn{3}{|c|}{ Without Citrus Canker } & \multicolumn{3}{|c|}{ With Endemic Citrus Canker } & \multirow[b]{2}{*}{ Net Effect } \\
\hline & $\begin{array}{c}\text { Average } \\
\text { F.O.B.* } \\
\text { Price } \\
\end{array}$ & Marketings & $\begin{array}{c}\text { Total } \\
\text { F.O.B. } \\
\text { Revenue } \\
\end{array}$ & $\begin{array}{c}\text { Average } \\
\text { F.O.B. } \\
\text { Price } \\
\end{array}$ & Marketings & $\begin{array}{c}\text { Total } \\
\text { F.O.B. } \\
\text { Revenue } \\
\end{array}$ & \\
\hline & $\$ /$ carton & $\begin{array}{c}1,000 \\
\text { cartons }\end{array}$ & $\begin{array}{l}1,000 \\
\text { dollars }\end{array}$ & $\$ /$ carton & $\begin{array}{r}1,000 \\
\text { cartons }\end{array}$ & $\begin{array}{r}1,000 \\
\text { dollars }\end{array}$ & $\begin{array}{r}1,000 \\
\text { dollars }\end{array}$ \\
\hline United States & 7.60 & 14,225 & 108,110 & 9.93 & 12,189 & 121,037 & 12,927 \\
\hline Canada & 7.80 & 2,086 & 16,271 & 10.19 & 1,799 & 18,332 & 2,061 \\
\hline European Union & 8.00 & 6,587 & 52,696 & - & 0 & 0 & $-52,696$ \\
\hline Japan & 10.80 & 4,999 & 53,989 & 14.16 & 2,780 & 39,364 & $-14,624$ \\
\hline World F.O.B. Revenue & & & 231,066 & & & 178,733 & $-52,333$ \\
\hline
\end{tabular}

Table 3. Estimated economic impact of endemic citrus canker on world F.O.B. revenue for white seedless grapefruit, 1999-2000 season.

\begin{tabular}{|c|c|c|c|c|c|c|c|}
\hline & \multicolumn{3}{|c|}{ Without Citrus Canker } & \multicolumn{3}{|c|}{ With Endemic Citrus Canker } & \multirow[b]{2}{*}{$\begin{array}{l}\text { Net } \\
\text { Effect }\end{array}$} \\
\hline & $\begin{array}{c}\text { Average } \\
\text { F.O.B. }{ }^{*} \\
\text { Price }\end{array}$ & Marketings & $\begin{array}{c}\text { Total } \\
\text { F.O.B. } \\
\text { Revenue }\end{array}$ & $\begin{array}{c}\text { Average } \\
\text { F.O.B. } \\
\text { Price } \\
\end{array}$ & Marketings & $\begin{array}{c}\text { Total } \\
\text { F.O.B. } \\
\text { Revenue }\end{array}$ & \\
\hline & $\$ /$ carton & 1,000 cartons & $\begin{array}{l}1,000 \\
\text { dollars }\end{array}$ & $\$ /$ carton & $\begin{array}{r}1,000 \\
\text { cartons }\end{array}$ & $\begin{array}{r}1,000 \\
\text { dollars }\end{array}$ & $\begin{array}{r}1,000 \\
\text { dollars }\end{array}$ \\
\hline United States & 8.03 & 1,488 & 11,949 & 10.34 & 1,296 & 13,401 & 1,452 \\
\hline Canada & 8.00 & 168 & 1,344 & 10.30 & 146 & 1,504 & 160 \\
\hline European Union & 8.20 & 248 & 2,034 & - & 0 & 0 & $-2,034$ \\
\hline Japan & 11.00 & 6,888 & 75,768 & 14.14 & 4,032 & 57,012 & $-18,756$ \\
\hline \multicolumn{2}{|c|}{ World F.O.B. Revenue } & & 91,094 & & & 71,917 & $-19,178$ \\
\hline
\end{tabular}


Table 4. Estimated economic impact of endemic citrus canker on F.O.B. cost for fresh market red grapefruit, 1999-2000 season.

\begin{tabular}{|c|c|c|c|c|c|c|}
\hline & \multicolumn{3}{|c|}{ Without Citrus Canker } & \multicolumn{3}{|c|}{ With Endemic Citrus Canker } \\
\hline Total Yield (boxes/acre) & \multicolumn{3}{|c|}{555} & \multicolumn{3}{|c|}{$500^{a}$} \\
\hline Total Yield (cartons/acre) & \multicolumn{3}{|c|}{1,110} & \multicolumn{3}{|c|}{1,000} \\
\hline Percent Packout & \multicolumn{3}{|c|}{$60 \%$} & \multicolumn{3}{|c|}{$40 \%$} \\
\hline Elimination Pound Solids Yield & \multicolumn{3}{|c|}{4.70 p.s./box } & \multicolumn{3}{|c|}{4.70 p.s./box } \\
\hline Elimination Processed Price & \multicolumn{3}{|c|}{$\$ 0.60 /$ p.s. } & \multicolumn{3}{|c|}{$\$ 0.65 /$ p.s. } \\
\hline Elimination Packinghouse Charge & \multicolumn{3}{|c|}{$\$ 1.00 / \mathrm{box}$} & \multicolumn{3}{|c|}{$\$ 1.00 / \mathrm{box}$} \\
\hline Harvesting/Pick-and-Haul Costs & \multicolumn{3}{|c|}{$\$ 2.325 / \mathrm{box}$} & \multicolumn{3}{|c|}{$\$ 2.325 / \mathrm{box}$} \\
\hline Growing Costs (per acre) & \multicolumn{3}{|c|}{$\$ 867.06$} & \multicolumn{3}{|c|}{$\$ 867.06$} \\
\hline \multicolumn{7}{|l|}{ Additional Costs (per acre): } \\
\hline Windbreaks & & & & & $\$ 44.89$ & \\
\hline \multirow[t]{2}{*}{ Copper Application (2 sprays) } & \multicolumn{3}{|c|}{ - } & \multicolumn{3}{|c|}{$\$ 59.08$} \\
\hline & $\$ /$ Acre & $\$ / B o x$ & \$/Carton & $\$ /$ Acre & $\$ / B o x$ & $\$ /$ Carton \\
\hline Total Growing/Cultural Costs & 867.06 & 2.604 & 1.302 & 971.03 & 4.855 & 2.428 \\
\hline Other Costs ${ }^{b}$ & 552.70 & 1.660 & 0.8299 & 552.70 & 2.7664 & 1.382 \\
\hline Harvesting (Pick/Spot Pick, Haul, DOC Tax) & $1,290.38$ & 3.875 & 1.9375 & $1,162.50$ & 5.813 & 2.906 \\
\hline Total Delivered-In Cost ${ }^{c}$ & $2,710.14$ & 8.139 & 4.0693 & $2,686.23$ & 13.439 & 6.719 \\
\hline Packing \& Selling Costs & $2,520.81$ & 7.570 & 3.7850 & $1,556.73$ & 7.781 & 3.892 \\
\hline Net Cost of Eliminations ${ }^{d}$ & -404.04 & -1.213 & -0.6067 & -615.50 & -3.078 & -1.541 \\
\hline Total F.O.B. ${ }^{*}$ Costs & $4,826.91$ & 14.495 & 7.248 & $3,627.46$ & 18.14 & 9.069 \\
\hline $\begin{array}{l}{ }^{a} \text { Assume yield reduction of } 10 \% \text { in citrus can } \\
{ }^{b} \text { Other Costs (interest on operating cost \& a } \\
{ }^{c} \text { Delivered-in Costs (total cost for fruit delive } \\
\text { harvesting/pick-and-haul costs). } \\
{ }^{d} \text { Net Eliminations Cost (the average yield of } \\
\text { charge and cannery hauling charge per box) } \\
{ }^{*} \text { F.O.B. = freight on board. } \\
\text { Source: Muraro, R.P., F.M. Roka, and R.E. F } \\
\text { Production, 1999-2000. Economic Informatio } \\
\text { Florida, Gainesville, FL (December). }\end{array}$ & $\begin{array}{l}\text { demic indu } \\
\text { capital inv } \\
\text { juice proces } \\
\text { solids per } \\
\text { 2000. Bud } \\
\text { ort El-00-07 }\end{array}$ & $\begin{array}{l}\text { try. } \\
\text { stment, ma } \\
\text { sor/fresh fr } \\
\text { ox times p } \\
\text { eting Cost } \\
\text { Departme }\end{array}$ & $\begin{array}{l}\text { nagement, a } \\
\text { it packer; in } \\
\text { ice per poun } \\
\text { and Return } \\
\text { tt of Food ar }\end{array}$ & $\begin{array}{l}\text { xes/regulat } \\
\text { s productio } \\
\text { ds less pac } \\
\text { Southwest } \\
\text { source Eco }\end{array}$ & $\begin{array}{l}\text { y cost). } \\
\text { cultural cos } \\
\text { nghouse el } \\
\text { omida Citrus } \\
\text { omics, Univ }\end{array}$ & $\begin{array}{l}\text { and } \\
\text { ination } \\
\text { sity of }\end{array}$ \\
\hline
\end{tabular}


Table 5. Estimated economic impact of endemic citrus canker on F.O.B. cost for fresh market white grapefruit, 1999-2000 season.

\begin{tabular}{|c|c|c|c|c|c|c|}
\hline & \multicolumn{3}{|c|}{ Without Citrus Canker } & \multicolumn{3}{|c|}{ With Endemic Citrus Canker ${ }^{a}$} \\
\hline Total Yield (boxes/acre) & \multicolumn{3}{|c|}{469} & \multicolumn{3}{|c|}{422} \\
\hline Total Yield (cartons/acre) & \multicolumn{3}{|c|}{938} & \multicolumn{3}{|c|}{844.2} \\
\hline Percent Packout & \multicolumn{3}{|c|}{$60 \%$} & \multicolumn{3}{|c|}{$40 \%$} \\
\hline Elimination Pound Solids Yield & \multicolumn{3}{|c|}{4.70 p.s./box } & \multicolumn{3}{|c|}{4.70 p.s./box } \\
\hline Elimination Processed Price & \multicolumn{3}{|c|}{$\$ 0.60 /$ p.s. } & \multicolumn{3}{|c|}{$\$ 0.65 /$ p.s. } \\
\hline Elimination Packinghouse Charge & \multicolumn{3}{|c|}{$\$ 1.00 / \mathrm{box}$} & \multicolumn{3}{|c|}{$\$ 1.00 / \mathrm{box}$} \\
\hline Harvesting/Pick-and-Haul Costs & \multicolumn{3}{|c|}{$\$ 2.325 / \mathrm{box}$} & \multicolumn{3}{|c|}{$\$ 2.325 / \mathrm{box}$} \\
\hline Growing Costs (per acre) & \multicolumn{3}{|c|}{$\$ 951.47$} & \multicolumn{3}{|c|}{$\$ 951.47$} \\
\hline \multicolumn{7}{|l|}{ Additional Costs (per acre): } \\
\hline Windbreaks & & & & & $\$ 44.89$ & \\
\hline \multirow{2}{*}{ Copper Application (2 sprays) } & \multicolumn{3}{|c|}{-} & \multicolumn{3}{|c|}{$\$ 59.08$} \\
\hline & $\$ A c r e$ & $\$ / B o x$ & \$/Carton & $\$ /$ Acre & $\$ / B o x$ & \$/Carton \\
\hline Total Growing/Cultural Costs & 951.47 & 3.381 & 1.691 & $1,055.44$ & 6.251 & 3.126 \\
\hline Other Costs ${ }^{\mathrm{b}}$ & 634.92 & 2.256 & 1.128 & 634.92 & 3.760 & 1.880 \\
\hline Harvesting (Pick/Spot Pick, Haul, DOC Tax) & $1,090.43$ & 3.875 & 1.938 & 981.387 & 5.813 & 2.906 \\
\hline Total Delivered-In Cost ${ }^{c}$ & $2,676.82$ & 9.513 & 4.756 & $2,671.747$ & 15.824 & 7.912 \\
\hline Packing \& Selling & $2,130.20$ & 7.570 & 3.785 & $1,312.22$ & 7.772 & 3.886 \\
\hline Net Cost of Eliminations ${ }^{d}$ & -341.43 & -1.213 & -0.6067 & -520.449 & -3.083 & -1.541 \\
\hline Total F.O.B. ${ }^{*}$ Costs & $4,465.59$ & 15.869 & 7.934 & $3,463.738$ & 20.513 & 10.257 \\
\hline $\begin{array}{l}{ }^{a} \text { Assume yield reduction of } 10 \% \text { in citrus can } \\
\text { b } \text { Other Costs (interest on operating/cultural c } \\
{ }^{c} \text { Delivered-in Costs (total cost for fruit delive } \\
\text { harvesting/pick-and-haul costs). } \\
{ }^{d} \text { Net Eliminations Cost (equals the average } \\
\text { elimination charge and cannery hauling char } \\
{ }^{\star} \text { F.O.B. = freight on board. } \\
\text { Source: Muraro, R.P., F.M. Roka, and R.E. F } \\
\text { Production, 1999-2000. Economic Informatio } \\
\text { of Florida, Gainesville, FL (December). }\end{array}$ & $\begin{array}{l}\text { ndemic ind } \\
\text { average c } \\
\text { juice proce } \\
\text { f pound so } \\
\text { box). } \\
\text { 2000. Buc } \\
\text { ort El-00-C }\end{array}$ & $\begin{array}{l}\text { pitry. } \\
\text { ssor/fresh } f \\
\text { ids per box } \\
\text { geting Cost } \\
\text { 7. Departme }\end{array}$ & $\begin{array}{l}\text { ent, manag } \\
\text { iit packer; it } \\
\text { mes price } \\
\text { and Returr } \\
\text { tt of Food a }\end{array}$ & $\begin{array}{l}\text { th and taxes } \\
\text { es productio } \\
\text { Sound solids I } \\
\text { esource Ecc }\end{array}$ & $\begin{array}{l}\text { egulatory } \\
\text { cultural co } \\
\text { s packing } \\
\text { orida Citrus } \\
\text { omics, Uni }\end{array}$ & $\begin{array}{l}\text { sts). } \\
\text { ts and } \\
\text { ersity }\end{array}$ \\
\hline
\end{tabular}


Table 6. Estimated economic impact of endemic citrus canker on total delivered-in costs for red seedless grapefruit grown for processed market, 1999-2000 season.

\begin{tabular}{|c|c|c|c|c|}
\hline & \multicolumn{2}{|c|}{ Without Citrus Canker } & \multicolumn{2}{|c|}{ With Endemic Citrus Canker } \\
\hline Total Yield (boxes/acre) & \multicolumn{2}{|c|}{555} & \multicolumn{2}{|c|}{$500^{a}$} \\
\hline Growing Costs (per acre) & \multicolumn{2}{|c|}{$\$ 682.92$} & \multicolumn{2}{|c|}{$\$ 682.92$} \\
\hline \multirow[t]{2}{*}{ Additional Costs (per acre): Copper Application } & \multicolumn{2}{|l|}{ - } & \multicolumn{2}{|c|}{$\$ 32.36$} \\
\hline & $\$ /$ Acre & $\$ / B o x$ & $\$ /$ Acre & $\$ / B o x$ \\
\hline Total Growing/Cultural Costs & 682.92 & 1.230 & 715.28 & 1.431 \\
\hline Other Costs ${ }^{\mathrm{b}}$ & 498.80 & 0.899 & 498.80 & 0.988 \\
\hline Total Grower Costs & $1,181.72$ & 2.219 & $1,214.08$ & 2.429 \\
\hline Harvesting (Pick/Spot Pick, Haul, DOC Tax, etc.) & $1,110.00$ & 2.000 & $1,110.00$ & 2.220 \\
\hline Total Delivered-in Costs ${ }^{c}$ & $2,291.72$ & 4.129 & 2,324.08 & 4.649 \\
\hline \multicolumn{5}{|c|}{$\begin{array}{l}\text { a Assume yield reduction of } 10 \% \text { in citrus canker endemic industry. } \\
{ }^{b} \text { Other Costs (interest on operating/cultural cost \& average capital investment, management, and taxes/regulatory cost). } \\
{ }^{c} \text { Delivered-in Costs (total cost for fruit delivered to juice processor/fresh fruit packer; includes production/cultural costs } \\
\text { and harvesting/pick-and-haul costs). } \\
\text { Source: Muraro, R.P., F.M. Roka, and R.E. Rouse. 2000. Budgeting Costs and Returns for Southwest Florida Citrus } \\
\text { Production, 1999-2000. Economic Information Report El-00-07. Department of Food and Resource Economics, } \\
\text { University of Florida, Gainesville, FL (December). }\end{array}$} \\
\hline
\end{tabular}

Table 7. Estimated economic impact of endemic citrus canker on total delivered-in costs for white seedless grapefruit grown for processed market, 1999-2000 season.

\begin{tabular}{|c|c|c|c|c|}
\hline & \multicolumn{2}{|c|}{ Without Citrus Canker } & \multicolumn{2}{|c|}{ With Endemic Citrus Canker } \\
\hline Total Yield (boxes/acre) & \multicolumn{2}{|c|}{469} & \multicolumn{2}{|c|}{$422^{\mathrm{a}}$} \\
\hline Growing Costs (per acre) & \multicolumn{2}{|c|}{$\$ 769.14$} & \multicolumn{2}{|c|}{$\$ 769.14$} \\
\hline \multirow[t]{2}{*}{ Additional Costs (per acre): Copper Application } & \multicolumn{2}{|c|}{ - } & \multicolumn{2}{|c|}{$\$ 32.36$} \\
\hline & $\$ /$ Acre & $\$ / B o x$ & $\$ /$ Acre & $\$ / B o x$ \\
\hline Total Growing/Cultural Costs & 769.14 & 1.640 & 801.50 & 1.899 \\
\hline Other Costs ${ }^{\mathrm{b}}$ & 608.83 & 1.298 & 608.83 & 1.442 \\
\hline Total Grower Costs & $1,377.97$ & 2.938 & $1,410.33$ & 3.341 \\
\hline Harvesting (Pick/Spot Pick, Haul, DOC Tax, etc.) & 961.45 & 2.050 & 961.45 & 2.278 \\
\hline Total Delivered-in Costs ${ }^{c}$ & $2,339.42$ & 4.988 & $2,371.78$ & 5.619 \\
\hline \multicolumn{5}{|c|}{$\begin{array}{l}{ }^{\mathrm{a}} \text { Assume yield reduction of } 10 \% \text { in citrus canker endemic industry. } \\
{ }^{\mathrm{b}} \text { Other Costs (interest on operating/cultural cost \& average capital investment, management, and taxes/regulatory cost). } \\
{ }^{\mathrm{c}} \text { Delivered-in Costs (total cost for fruit delivered to juice processor/fresh fruit packer; includes production/cultural costs } \\
\text { and harvesting/pick-and-haul costs). } \\
\text { Source: Muraro, R.P., F.M. Roka, and R.E. Rouse. 2000. Budgeting Costs and Returns for Southwest Florida Citrus } \\
\text { Production, 1999-2000. Economic Information Report El-00-07. Department of Food and Resource Economics, } \\
\text { University of Florida, Gainesville, FL (December). }\end{array}$} \\
\hline
\end{tabular}


Florida's Citrus Canker Eradication Program (CCEP): Annual Economic Impact on Florida's....

Table 8. Estimated net change in revenues for fresh and processed red seedless and white seedless grapefruit associated with endemic citrus canker.

\begin{tabular}{|lccc|}
\hline \hline \multicolumn{1}{|c}{ Variety } & \multicolumn{2}{c|}{ On-tree Revenue* } \\
& Without Citrus Canker & With Citrus Canker & Net Revenue Change \\
\hline Fresh Market & 76,982 & & \\
Red Seedless Grapefruit & 41,770 & 83,814 & 6,832 \\
White Seedless Grapefruit & & 40,693 & $-1,077$ \\
\hline Processed Market & 30,342 & 21,575 & $-8,767$ \\
Red Seedless Grapefruit & 39,078 & 28,862 & $-10,216$ \\
White Seedless Grapefruit & & Estimated Net Revenue Change: & $-13,229$ \\
& & & \\
\hline * On-Tree Revenue (farm gate price after harvesting/pick-and-haul cost have been subtracted). \\
\hline \hline
\end{tabular}

Table 9. Estimated net change in world F.O.B. revenues for red seedless and white seedless grapefruit associated with endemic citrus canker.

\begin{tabular}{|lccc|}
\hline \hline \multicolumn{1}{|c}{ Variety } & & F.O.B. ${ }^{*}$ Revenue & \\
& Without Citrus Canker & With Citrus Canker & Net Change in Revenue \\
\hline Red Seedless Grapefruit & 108,110 & & \\
United States & 16,271 & 121,037 & 12,927 \\
Canada & 52,696 & 18,332 & 2,061 \\
European Union & 53,989 & - & $-52,696$ \\
Japan & & Estimated Net Revenue Change: & $-14,624$ \\
& & 39,364 & $-52,333$ \\
\hline White Seedless Grapefruit & 11,949 & 13,401 & 1,452 \\
United States & 1,344 & 1,504 & 160 \\
Canada & 2,034 & - & $-2,034$ \\
European Union & 75,768 & 57,012 & $-18,756$ \\
Japan & & Estimated Net Revenue Change: & $-19,177$ \\
\hline * F.O.B. = freight on board. & & & \\
\hline \hline
\end{tabular}


Florida's Citrus Canker Eradication Program (CCEP): Annual Economic Impact on Florida's....

Table 10. Estimated net change in cost of production of red seedless and white seedless grapefruit.

\begin{tabular}{|c|c|c|c|}
\hline \multirow[t]{2}{*}{ Variety } & \multicolumn{3}{|c|}{ Total Production Costs } \\
\hline & Without Citrus Canker & With Citrus Canker & Net Cost Change \\
\hline \multicolumn{4}{|l|}{ Field-Run } \\
\hline Red Seedless Grapefruit & 27,666 & 25,565 & $(2,101)$ \\
\hline White Seedless Grapefruit & 50,379 & 51,077 & 698 \\
\hline \multicolumn{4}{|l|}{ Packinghouse } \\
\hline Red Seedless Grapefruit & 365,299 & 411,370 & 46,071 \\
\hline \multirow[t]{2}{*}{ White Seedless Grapefruit } & 171,374 & 199,396 & 28,022 \\
\hline & & Estimated Cost Change: & 72,690 \\
\hline
\end{tabular}

Table 11. Summary of the annual net effect and economic impact of citrus canker on "on-tree" and F.O.B. revenues and delivered-in costs of fresh and processed grapefruit.

\begin{tabular}{|lcc|}
\hline \hline & & $\begin{array}{c}\text { Net Change } \\
1,000 \text { dollars }\end{array}$ \\
\hline $\begin{array}{l}\text { Estimated Net Reduction in On-Tree Revenue } \\
\text { Estimated Net Reduction in F.O.B. Revenue } \\
\text { Red Seedless Grapefruit }\end{array}$ & 13,229 \\
$\quad$ White Seedless Grapefruit & 52,333 & \\
$\quad$ Total Reduction in F.O.B. Revenue & 19,177 & 71,510 \\
Estimated Net Increase in Production Costs & & \\
$\quad$ Red Seedless Grapefruit & 43,970 & \\
White Seedless Grapefruit & 28,718 & 72,690 \\
Total Increase in Production Costs & & 157,429 \\
Total Annual Reduced Revenues and Increased Costs & & \\
\hline \hline
\end{tabular}

